\title{
Introduced birds on Assumption Island a threat to Aldabra
}

\author{
Peter Roberts
}

\begin{abstract}
When the Indian Ocean atoll of Aldabra was added to the World Heritage List in 1982 it concluded 20 years of conservation effort to gain international recognition of its scientific importance. Its native wildlife, which is still remarkably intact, is, however, under threat. Only 27 km away, on Assumption Island, introduced bird species have established and are breeding. The author made a survey in October 1986 and among his findings was the particularly alarming discovery of a large population of red-whiskered bulbuls Pycnonotus jocosus, a nest predator of small passerines. Urgent action is required to remove the introduced species from Assumption, not only to protect Aldabra, but also to pave the way for conservation efforts on Assumption itself.
\end{abstract}

Aldabra atoll $\left(9^{\circ} 25^{\prime} \mathrm{S}, 46^{\circ} 26^{\prime} \mathrm{E}\right)$ lies in the Indian Ocean some $800 \mathrm{~km}$ south-west of the central, granitic islands of the Seychelles, of which it is politically a part. It is closer (about $640 \mathrm{~km}$ ) to the African coast, and just $420 \mathrm{~km}$ north-west of Madagascar, from where much of its unique flora and fauna originated. Like the other outlying islands of the Seychelles, it is low-lying and coralline in structure, but is by far the largest, with a land area of about $155 \mathrm{sq} \mathrm{km}$. It is a perfect example of a raised coral atoll, with a land rim divided into four main islands enclosing a lagoon some $28 \mathrm{~km}$ long. Unlike the other outlying islands its ecosystem is remarkably intact, with an impressive array of plant and animal life, including many endemic forms. Most famous of these is the large population of giant tortoise Geochelone gigantea, now extinct on all other Indian Ocean islands. Recognition of the unique, unspoilt environment of Aldabra came with the award of World Heritage status in 1982 (Stoddart and Ferrari, 1983).

Within the same remote archipelago are three other islands: Astove, Cosmoledo and Assumption. Astove and Cosmoledo have both been exploited as coconut plantations, amongst other activities, and have lost much of their native wildlife, although Cosmoledo may still hold important Threat to Aldabra colonies of boobies Sula spp. Assumption has suffered more severe ravages through guano mining, carried out from early this century to the end of the 1970s, when depleted deposits and depressed world markets made it uneconomical. The island is now abandoned and depopulated, but during the 70 years of mining a large workforce systematically cleared much of the native vegetation to reach the deposits. This and earlier depredations have greatly depleted, and in many cases exterminated, native species. The island once boasted populations of Abbott's booby Sula abbotti and white-throated rail Dryolimnas cuvieri, as well as giant tortoises, but these have disappeared along with almost all other breeding land and sea birds.

The history of the degradation of Assumption's ecosystem up to 1967 was documented by Stoddart et al. (1970), and information on birds was updated after further week-long surveys in April 1977 and October/November 1978 by Prŷs-Jones et al. (1981). Prior to 1977 the only published record of exotic wild birds within the Aldabra archipelago related to a few barred ground doves Geopelia striata on Cosmoledo (Benson, 1970; Penny, 1974). In that year, however, Prŷs-Jones et al. (1981) recorded no fewer than six introduced alien species on 


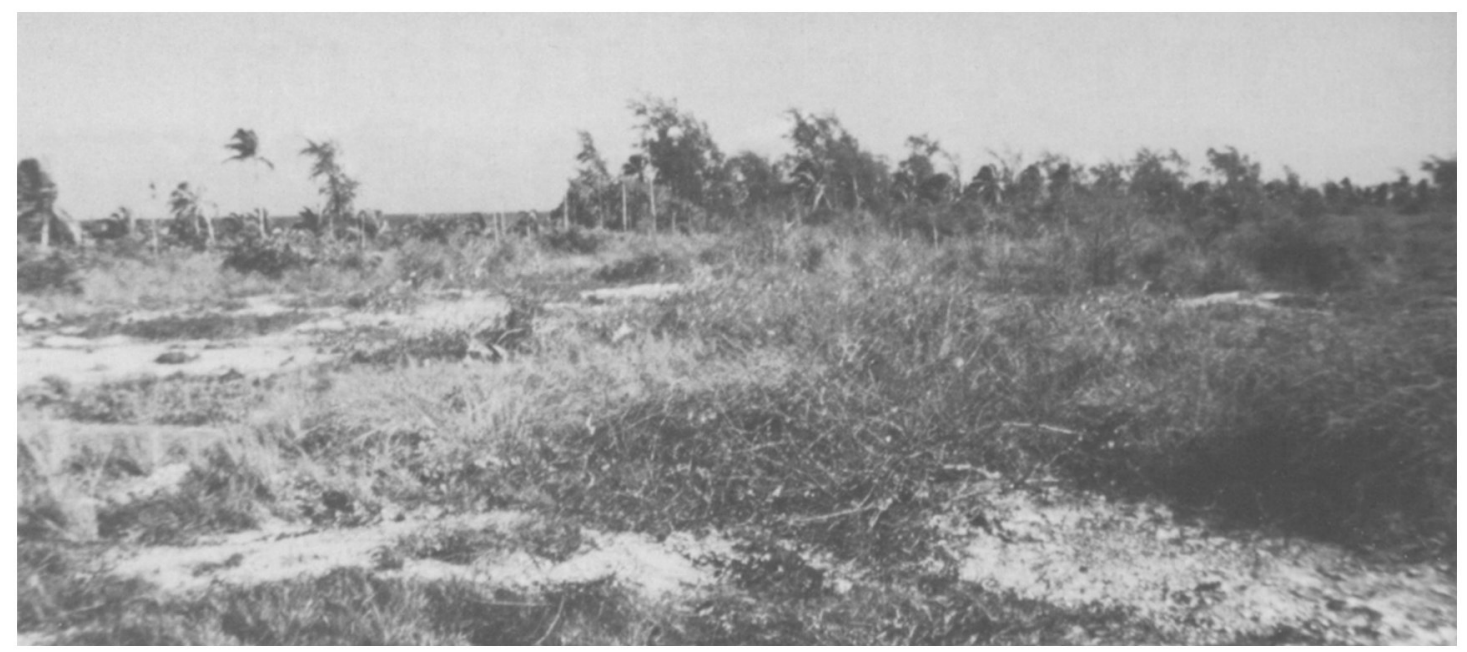

Vegetation regrowing after abandonment of guano mining on Assumption ( $P$. Roberts).

Assumption. Of these, the island manager was observed releasing 20-30 Malagasy fodies Foudia madagascariensis and a similar number of Mozambique serins Serinus mozambicus after shipment from Mauritius, and he also mentioned having previously released barred ground doves in 1976. At least seven of the latter species were present in 1977, including a breeding pair. No information was obtained regarding the background to the single grey-headed lovebird Agapornis cana and common waxbill Estrilda astrild or at least six red-whiskered bulbuls Pycnonotus jocosus observed in 1977. Data from 1978 suggested that most of the introductions were proving unsuccessful, with the only alien birds seen being about a dozen barred ground doves.

I visited Assumption from 25-27 October 1986, eight years after the last published bird records, and carried out the first survey since mining ceased and the island became depopulated. During this time I was able to cover the $10.5 \mathrm{sq} \mathrm{km}$ of the island fairly completely, except for the north-eastern coastal region. Among the indigenous land birds, the endemic subspecies of the Souimanga sunbird Nectarinia sauimanga abbotti remained an ubiquitous breeding species, but the 10-15 pied crows Corvus alba and about 35 cattle egrets Bubulcus ibis were only about half the number observed in 1977. I could not find either lovebirds or waxbills, but the other four 16 introduced species were all present. There were between six and eight pairs of barred ground doves, all confined to the now deserted settlement area. Both the Malagasy fody and Mozambique serin numbered 25-35 individuals, spread well over the island and utilizing most habitat types; several males in breeding plumage were observed. More alarming were the numbers of red-whiskered bulbuls. I counted about 100 pairs on just part of the island and estimated that the total could be twice that. The bulbuls were spread widely throughout the island: around the old settlement, with its now overgrown tangle of natural and introduced plant species; in coastal Pemphis and Suriana scrub; on the 25-m-high dunes covered with Scaevola, Suriana and Toumefortia shrubs along the south-east coast; and on extensive areas of the island's centre, previously cleared for mining and now regenerating. Numerous individuals were singing from bush tops, a nest with three eggs was found in an Acalypha bush and newly fledged young were present.

At its closest point, Aldabra lies just $27 \mathrm{~km}$ northwest of Assumption, and this proximity means that these alien bird species pose a very real threat to the unique Aldabran flora and fauna. Pied crows and Malagasy turtle doves Streptopelia picturata have been observed to move similar distances between atolls (Benson and Penny, 1971; R. Prŷs-Jones, unpubl.; P. Roberts, pers. Oryx Vol 22 No 1, January 1988 
obs.). Land birds have been known to fly from Aldabra to Assumption, and there seems no reason why the reverse could not happen also. Prŷs-Jones et al. (1981) pointed out that the naturally occurring red-headed forest fody Foudia eminentissima and Malagasy bulbul Hypsipetes madagascariensis of Aldabra are ecological counterparts to the introduced Malagasy fody and red-whiskered bulbul of Assumption, and reviewed potential threats posed to the Aldabra avifauna from disease, hybridization and competition. General concern over the introductions to Assumption was strongly reiterated by Diamond (1985) who stated that 'Firmer management on Assumption must become part of the conservation management of Aldabra'. Cheke (1987) subsequently drew particular attention to the danger of allowing introductions of the red-whiskered bulbul on to any more tropical Indian Ocean islands. It is well established on Mauritius (Long, 1981), and is an assertive species implicated in nest predation on other small passerines. My findings regarding the status of alien bird species on Assumption in 1986 must, therefore, be cause for extreme concern.

Much effort is currently being put into re-establishing and maintaining a natural ecosystem on Aldabra. A recent study has been completed on the feral cats (Seabrook, 1987), there is an ongoing programme to eradicate feral goats (Koblentz, 1987), and a proposed programme to eradicate an alien coccid bug (D.R. Stoddart, pers. comm.). It would seem particularly important to add the removal of exotic bird species on Assumption to this programme of safeguards. This work would best be done soon, before the vegetation fully regenerates, when trapping would be fairly simple and while numbers of birds are still small enough to make total eradication a possibility. Once completed, attention could be given to a further programme of re-introductions to Assumption of those Aldabran landbirds that formerly occurred there, the results of which could have major conservation benefits.

\section{Acknowledgments}

Thanks are due to the crew of the yacht Mirage 1 for transportation between Aldabra and Assumption, and to R. PrŷsJones for constructive comments on an earlier draft of this note.

Threat to Aldabra

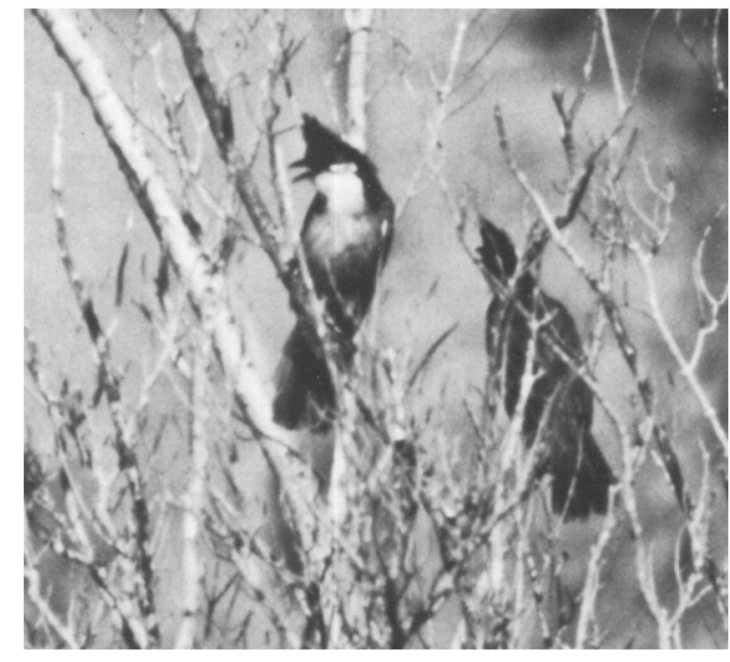

Red-whiskered bulbuls on Assumption (P. Roberts).

\section{References}

Benson, C.W. 1970 Land (including shore) birds of Cosmoledo. Atoll Res. Bull. 136, 67-81.

Benson, C.W. and Penny, M.J. 1971. The land birds of Aldabra. Phil. Trans. R. Soc. Lond. B 260, 417-527.

Cheke, A. 1987. An ecological history of the Mascarene Island birds. In Studies of Mascarene Island birds. (Ed. A.W. Diamond) Cambridge University Press, Cambridge.

Diamond, A.W. 1985. The conservation of landbirds on islands in the tropical Indian Ocean. ICBP Tech. Publ. 3, 85-100.

Koblentz, B.E. 1987. Biology and control of feral goats on Aldabra atoll. Unpub. Rept to Seychelles Islands Foundation, Mahe.

Long, J.L. 1981. Introduced Birds of the World. David \& Charles, Newton Abbott.

Penny, M.J. 1974. The Birds of the Seychelles and Outlying Islands. Collins, London.

Prŷs-Jones, R., Prŷs-Jones, M.S. and Lawley, J.C. 1981. The birds of Assumption Island, Indian Ocean: past and future. Atoll Res. Bull. 248, 1-16.

Seabrook, W. 1987. Examination of the impact of the feral cat (Felis catus L.) on the fauna of Aldabra atoll, Seychelles, with recommendations on management. Unpub. Rept WWF and Seychelles Island Foundation. Project No. 1784.

Stoddart, D.R., Benson, C.W. and Peake, J.F. 1970. Ecological change and effects of phosphate mining on Assumption Island. Atoll Res. Bull. 136, 121-145.

Stoddart, D.R. and Ferrari, J.D.M. 1983. Aldabra atoll: a stunning success story for conservation. Nature and Resources 19,20-28.

P.J. Roberts, 3 Childscroft Road, Rainham, Kent ME8 7ST, UK. 